\title{
Reductive Elimination of Aryl Halides from Monomeric Arylpalladium(II) Halide Complexes
}

Amy H. Roy and John F. Hartwig

Department of Chemistry, Yale University

P.O. Box 208107, New Haven, CT 06520-8107

\section{Supporting Information}

General Methods. All manipulations were conducted in an inert atmosphere dry box

unless otherwise noted. ${ }^{31} \mathrm{P}\left\{{ }^{1} \mathrm{H}\right\}$ NMR spectra were recorded on a GE Omega 300 NMR spectrometer. Chemical shifts are referenced to $85 \% \mathrm{H}_{3} \mathrm{PO}_{4}$ as an external standard. ${ }^{1} \mathrm{H} \mathrm{NMR}$ spectra were recorded on a 400 or $500 \mathrm{MHz}$ spectrometer, and chemical shifts are referenced to tetramethylsilane. All solvents were dried under sodium/benzophenone and distilled under $\mathrm{N}_{2}$ into an airtight container. Complex 1e was prepared according to literature procedures. ${ }^{1}$

Synthesis of $\mathbf{P d}\left[\mathbf{P}(\boldsymbol{t} \text {-Bu })_{3}\right](\boldsymbol{o}$-tolyl)(Cl) (1a). Into a $20 \mathrm{~mL}$ vial was placed $110 \mathrm{mg}$ $(0.230 \mathrm{mmol})$ of $\mathbf{1 b}$ and $65 \mathrm{mg}(0.25 \mathrm{mmol})$ of AgOTf. THF $(5 \mathrm{~mL})$ was added, and the suspension was stirred at room temperature for $10 \mathrm{~min}$. The $\mathrm{AgBr}$ precipitate was filtered from solution, $\mathrm{KCl}(28 \mathrm{mg}, 0.37 \mathrm{mmol})$ was added to the clear yellow solution, and the suspension was stirred at room temperature for $20 \mathrm{~min}$. At this time, ${ }^{31} \mathrm{P}\left\{{ }^{1} \mathrm{H}\right\}$ NMR spectroscopy showed complete conversion to the arylpalladium chloride. The precipitate was filtered from solution, and the solvent was evaporated under vacuum. Benzene was added to ensure complete 
precipitation of all salts in solution, the suspension was filtered, and the solvent was again removed under vacuum. The remaining yellow solid was washed with pentane and dried under vacuum to produce $51 \mathrm{mg}(51 \%$ yield $)$ of $\mathrm{Pd}\left[\mathrm{P}(t-\mathrm{Bu})_{3}\right](o$-tolyl $)(\mathrm{Cl}) .{ }^{1} \mathrm{H} \mathrm{NMR}\left(\mathrm{C}_{6} \mathrm{D}_{6}\right) \delta 1.27(\mathrm{~d}$, $J=12.4 \mathrm{~Hz}, 27 \mathrm{H}), 3.08(\mathrm{~s}, 3 \mathrm{H}), 6.77-6.83(\mathrm{~m}, 3 \mathrm{H}), 7.52-7.55(\mathrm{~m}, 1 \mathrm{H}) .{ }^{13} \mathrm{C} \mathrm{NMR}\left(\mathrm{CD}_{2} \mathrm{Cl}_{2}\right) \delta$ $27.68(\mathrm{~d}, J=3.1 \mathrm{~Hz}), 32.79(\mathrm{~d}, J=3.0 \mathrm{~Hz}), 41.03$ (d, J=9.6 Hz), 124.17, 124.34 (d, J=2.9 Hz), 128.86, $136.22(\mathrm{~d}, J=4.9 \mathrm{~Hz}), 139.25(\mathrm{~d}, J=6.8 \mathrm{~Hz}), 141.80 .{ }^{31} \mathrm{P} \mathrm{NMR}\left(\mathrm{C}_{6} \mathrm{D}_{6}\right) \delta$ 71.5. Anal. calc'd for $\mathrm{C}_{19} \mathrm{H}_{34} \mathrm{PClPd}$ : C, 52.42; H, 7.89. Found: C, 52.61; H, 7.94.

Synthesis of $\mathbf{P d}\left[\mathbf{P}(t-B u)_{3}\right](\boldsymbol{o}$-tolyl)(Br) (1b). Into a $20 \mathrm{~mL}$ vial was placed $300 \mathrm{mg}$ $(0.588 \mathrm{mmol})$ of $\mathrm{Pd}\left[\mathrm{P}(t-\mathrm{Bu})_{3}\right]_{2}$. Next, $4.5 \mathrm{~mL}$ of 2-bromotoluene were syringed into the vial, and the suspension was heated at $70{ }^{\circ} \mathrm{C}$. The starting material completely dissolved in the aryl bromide before completion of the reaction. The vial was removed from the $70{ }^{\circ} \mathrm{C}$ bath when side product began to accumulate, as judged by ${ }^{31} \mathrm{P}$ NMR spectroscopy. The yellow solution was transferred to a $100 \mathrm{~mL}$ round bottom flask, $60 \mathrm{~mL}$ of pentane were added to the flask, and the solution was stirred vigorously for $30 \mathrm{~min}$ to precipitate the product. The yellow solid was filtered, washed with pentane, and dried under vacuum to produce $199 \mathrm{mg}$ (70\% yield) of $\mathrm{Pd}[\mathrm{P}(t$ $\left.\mathrm{Bu})_{3}\right](o$-tolyl $)(\mathrm{Br}) .{ }^{1} \mathrm{H}$ NMR $\left(\mathrm{C}_{6} \mathrm{D}_{6}\right) \delta 1.06(\mathrm{~d}, J=12.4 \mathrm{~Hz}, 27 \mathrm{H}), 3.08(\mathrm{~s}, 3 \mathrm{H}), 6.69-6.82(\mathrm{~m}, 3 \mathrm{H})$, $7.35(\mathrm{dd}, J=2.8,7.8 \mathrm{~Hz}, 1 \mathrm{H}) .{ }^{13} \mathrm{C} \mathrm{NMR}\left(\mathrm{CD}_{2} \mathrm{Cl}_{2}\right) \delta 28.85(\mathrm{~d}, J=3.0 \mathrm{~Hz}), 32.33(\mathrm{~d}, J=3.1 \mathrm{~Hz})$, $41.02(\mathrm{~d}, J=10.8 \mathrm{~Hz}), 124.76,124.95(\mathrm{~d}, J=2.9 \mathrm{~Hz}), 129.68,135.12$ (d, J=4.4 Hz), 135.44 (d, 
$J=5.3 \mathrm{~Hz}), 140.53 .{ }^{31} \mathrm{P}\left\{{ }^{1} \mathrm{H}\right\} \mathrm{NMR}\left(\mathrm{C}_{6} \mathrm{D}_{6}\right) \delta 64.4$ (s). Anal. calc'd for $\mathrm{C}_{19} \mathrm{H}_{34} \mathrm{PBrPd}: \mathrm{C}, 47.56 ; \mathrm{H}$, 7.16. Found: C, 47.33; H, 7.08.

Synthesis of $\operatorname{Pd}\left[\mathbf{P}(t-B u)_{3}\right](o-t o l y l)(I)$ (1c). A similar procedure to that used to prepare 1b was used, but with 2-iodotoluene instead of 2-bromotoluene. The orange product was isolated after precipitation in $76 \%$ yield. ${ }^{1} \mathrm{H} \mathrm{NMR}\left(\mathrm{C}_{6} \mathrm{D}_{6}\right) \delta 0.99(\mathrm{~d}, J=12.8 \mathrm{~Hz}, 27 \mathrm{H}), 3.02$ (s, $3 \mathrm{H}), 6.66-6.75(\mathrm{~m}, 3 \mathrm{H}), 7.26(\mathrm{dd}, J=3.2,8.0 \mathrm{~Hz}, 1 \mathrm{H}) .{ }^{13} \mathrm{C} \mathrm{NMR}\left(\mathrm{CD}_{2} \mathrm{Cl}_{2}\right) \delta 30.16(\mathrm{~d}, J=2.3 \mathrm{~Hz})$, $32.29(\mathrm{~d}, J=2.1 \mathrm{~Hz}), 41.27(\mathrm{~d}, J=7.5 \mathrm{~Hz}), 124.62,124.71$ (d, J=3.5 Hz), 129.15, 134.13 (d, $J=6.4$ $\mathrm{Hz}), 135.20(\mathrm{~d}, J=5.0 \mathrm{~Hz}), 139.62(\mathrm{~d}, J=1.6 \mathrm{~Hz}) .{ }^{31} \mathrm{P}\left\{{ }^{1} \mathrm{H}\right\} \mathrm{NMR}\left(\mathrm{C}_{6} \mathrm{D}_{6}\right) \delta 58.6(\mathrm{~s})$. Anal. calc'd for $\mathrm{C}_{19} \mathrm{H}_{34}$ PIPd: $\mathrm{C}, 43.32 ; \mathrm{H}, 6.52$. Found: $\mathrm{C}, 43.55 ; \mathrm{H}, 6.40$.

Synthesis of $\mathbf{P d}\left[\mathbf{P}(t-\mathbf{B u})_{3}\right](\mathbf{P h})(\mathbf{B r})(\mathbf{1 d})$. A similar procedure to that used to prepare $\mathbf{1 b}$ was used, but with bromobenzene instead of 2-bromotoluene. The yellow product was isolated after precipitation in $63 \%$ yield. ${ }^{1} \mathrm{H} \mathrm{NMR}\left(\mathrm{C}_{6} \mathrm{D}_{6}\right) \delta 1.02(\mathrm{~d}, J=12.5 \mathrm{~Hz}, 27 \mathrm{H}), 6.75(\mathrm{t}, J=7.0 \mathrm{~Hz}$, $1 \mathrm{H}), 6.82(\mathrm{t}, J=7.0 \mathrm{~Hz}, 2 \mathrm{H}), 7.43(\mathrm{dd}, J=2.5,8.0 \mathrm{~Hz}, 2 \mathrm{H}) .{ }^{13} \mathrm{C} \mathrm{NMR}\left(\mathrm{CD}_{2} \mathrm{Cl}_{2}\right) \delta 32.28(\mathrm{~d}, J=3.0$ Hz), 41.16 (d, J=9.9 Hz), 124.38, 127.65 (d, J=2.0 Hz), 134.19 (br), 136.40 (d, J=2.5 Hz). ${ }^{31} \mathrm{P}\left\{{ }^{1} \mathrm{H}\right\} \operatorname{NMR}\left(\mathrm{C}_{6} \mathrm{D}_{6}\right) \delta 63.5$ (s). Anal. calc'd for $\mathrm{C}_{18} \mathrm{H}_{32} \mathrm{PBrPd}: \mathrm{C}, 46.41 ; \mathrm{H}, 6.94$. Found: $\mathrm{C}$, 46.10; H, 6.64.

Measurement of Rate Constants for Reductive Elimination of Aryl Halide from Pd(II) Monomers: Representative Procedure for Measurement of $\mathbf{P}(t-\mathrm{Bu})_{3}$ Dependence. $\mathrm{Pd}\left[\mathrm{P}(\mathrm{t}-\mathrm{Bu})_{3}\right](o$-tolyl $)(\mathrm{Br})(5.0 \mathrm{mg}, 0.010 \mathrm{mmol})$ was placed into a small vial and dissolved in 
$0.49 \mathrm{~mL}$ of $\mathrm{C}_{6} \mathrm{D}_{6}$. Next, $0.11 \mathrm{~mL}(0.12 \mathrm{mmol})$ of a $1.05 \mathrm{M}$ solution of $\mathrm{P}(t-\mathrm{Bu})_{3}$ in $\mathrm{C}_{6} \mathrm{D}_{6}$ were syringed into the vial, followed by $5.0 \mu \mathrm{L}$ of 2-bromotoluene and $47 \mu \mathrm{L}(0.010 \mathrm{mmol})$ of a 0.22 M solution of 1,3,5-trimethoxybenzene in $\mathrm{C}_{6} \mathrm{D}_{6}$. This solution was transferred to a septum-lined, screw-capped NMR tube. The sample was inserted into a GE Omega 300 NMR, heated to 65 ${ }^{\circ} \mathrm{C}$, and ${ }^{1} \mathrm{H}$ NMR spectra were obtained every 3 min over the course of approximately $4 \mathrm{~h}$.

\section{Measurement of Rate Constants for Reductive Elimination of Aryl Halide from}

Pd(II) Monomers: Representative Procedure for Measurement of Bromoarene

Dependence. $\mathrm{Pd}\left[\mathrm{P}(\mathrm{t}-\mathrm{Bu})_{3}\right](o$-tolyl $)(\mathrm{Br})(5.0 \mathrm{mg}, 0.010 \mathrm{mmol})$ was placed into a small vial and dissolved in $70 \mu \mathrm{L}$ of $\mathrm{C}_{6} \mathrm{D}_{6}$. Next, $0.53 \mathrm{~mL}(0.52 \mathrm{mmol})$ of a $0.99 \mathrm{M}$ solution of $\mathrm{P}(t-\mathrm{Bu})_{3}$ in $\mathrm{C}_{6} \mathrm{D}_{6}$ were syringed into the vial, followed by $47 \mu \mathrm{L}(0.010 \mathrm{mmol})$ of a $0.22 \mathrm{M}$ solution of $1,3,5-$ trimethoxybenzene in $\mathrm{C}_{6} \mathrm{D}_{6}$ and $7.6 \mu \mathrm{L}(0.063 \mathrm{mmol})$ of 2-bromotoluene. This solution was transferred to a septum-lined, screw-capped NMR tube. The sample was inserted into a GE Omega $300 \mathrm{NMR}$, heated to $65{ }^{\circ} \mathrm{C}$, and ${ }^{1} \mathrm{H}$ NMR spectra were obtained every 5 min over the course of approximately $5 \mathrm{~h}$.

\section{Determination of Equilibrium Constants for the Reductive Elimination of Aryl} Halide from Pd(II) Monomers: Representative Procedure. To determine the equilibrium constant starting from the arylpalladium halide complexes, a sample was prepared by dissolving $5.0 \mathrm{mg}(0.010 \mathrm{mmol}) \quad$ of $\operatorname{Pd}\left[\mathrm{P}(t-\mathrm{Bu})_{3}\right](o$-tolyl $)(\mathrm{Br}), 2.2 \mathrm{mg}(0.013 \mathrm{mmol})$ of $1,3,5-$ trimethoxybenzene, and $4.3 \mathrm{mg}(0.021 \mathrm{mmol})$ of $\mathrm{P}(t-\mathrm{Bu})_{3}$ in $0.60 \mathrm{~mL}$ of $\mathrm{C}_{6} \mathrm{D}_{6}$. The solution was 
mixed and transferred to a septum-lined, screw-capped NMR tube. The sample was heated at 70 ${ }^{\circ} \mathrm{C}$, and ${ }^{1} \mathrm{H}$ NMR spectra were obtained periodically until the integration ratios remained constant. A final ${ }^{1} \mathrm{H}$ NMR spectrum was obtained. Concentrations of all species were calculated, from which a $K_{\text {eq }}$ value was then determined. To obtain $K_{\text {eq }}$ for the oxidative addition to $\operatorname{Pd}[\mathrm{P}(t-$ $\left.\mathrm{Bu})_{3}\right]_{2}$, a sample was prepared by dissolving $\mathrm{Pd}\left[\mathrm{P}(t-\mathrm{Bu})_{3}\right]_{2}, \mathrm{P}(t-\mathrm{Bu})_{3}, 2$-bromotoluene, and 1,3,5trimethoxybenzene in $0.60 \mathrm{~mL}$ of $\mathrm{C}_{6} \mathrm{D}_{6}$. The procedure for acquisition of data was the same as that for the reaction run in the forward direction.

\section{References}

(1) Stambuli, J. P.; Buhl, M.; Hartwig, J. F. J. Am. Chem. Soc. 2002, 124, 9346-9347. 